\title{
ASSESSMENT OF QUALITY IN INDIAN HIGHER EDUCATION (WITH SPECIAL REFERENCE TO ENGINEERING STREAM)
}

* Dr. G.MANCHALA

\author{
** SYEDA AMINA BEGUM
}

\begin{abstract}
Quality is never an accident; it is always the result of high intention, sincere effort, intelligent direction, and skillful execution; it represents the wide choice of many alternatives as said by William A Foster. In view of this proverb the present article is written. Quality initiative is the need of the hour today especially in engineering stream as it is the hot cake of students' choice. In this article an attempt is made to know what exactly engineering faculties and students need to embrace quality in the institutes which is lacking in quality initiatives. This article highlights the need for change in Institute attitude to look for quality improvements at their levels and to provide the facilities for which an exhaustive list of more than 50 points has been noted in this article.
\end{abstract}

Keywords: Quality, Intelligent Direction, Skillful execution, Quality initiative

\section{INTRODUCTION}

**Educating the mind without educating the heart is no education at all ---- Aristotle**.

The Government of India encouraged the spread of higher education. In the past decade, there has been a sharp increase in the number of private colleges as well as universities in India with the status of either deemed to be universities or state universities; higher education is continuing to expand, mostly in an unplanned manner, without even minimum levels of checks and balances (Umashankar and Dutta, 2007). What should guide the higher education in order to achieve excellencefl Higher education should be guided through Service Quality concepts to achieve excellence (Kanji and Tambi, 1999). Service quality concept is considered as an integrated system of principles, methods and best practices that will provide a framework for organizations to strive for excellence in everything they do (Srdoc, A., Sluga, A, and Bratko, I.2005). The concepts and principles of Quality Management, which are effectively used in today's competitive production and business environments, have become indispensable in today's business of higher education (Hwarng and Teo, 2001). Higher education plays a vital role in socio economic development of the nation. Indian education system has made a significant progress in higher education from past two decades.

Governments at the state and central levels with

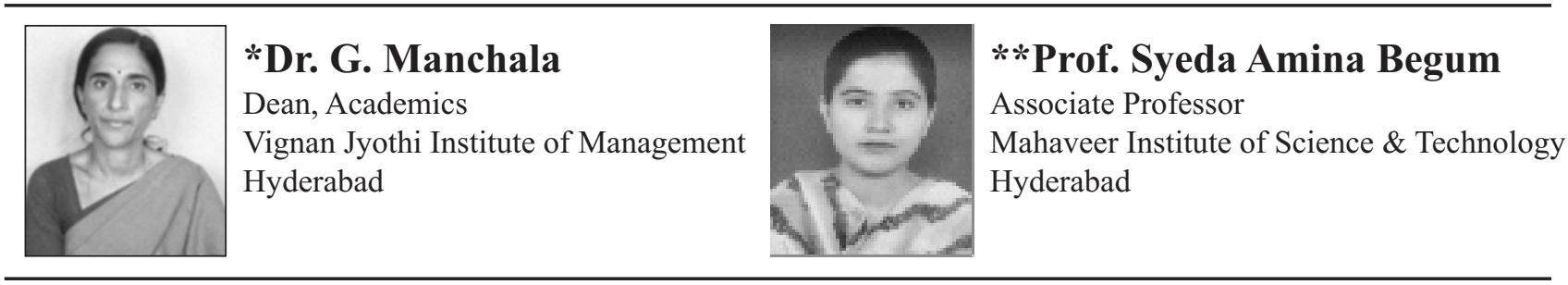


various regulatory and accreditation bodies, monitor the higher educational institutions with a vision to ensure quality in educational services, yet, quality of higher education is struggling to attain the global level excellence in India. In addition, the expansion of institutions with lack of proper infrastructure and funds from government caused the mushrooming of private institutions in India. Therefore, quality has become an important drive for socio development and also, it becomes a competitive weapon for the institutions to attract and serves the students as primary customer. Students are the primary customers in an educational set up and it is strongly supported by many researchers. Students involve in different roles: they are the product of the process, the internal customer for campus facilities, the laborers of the learning process and the internal customer of the delivery of the course material. However, it is generally accepted that students are the primary customers and other prospective customers are such as alumni, parents, employers, employee, Government, industry and society may be considered secondary customers. Different studies examined the viewpoints of different professionals and experts on the quality in higher education and concluded that customer - orientation in higher education is a generally acceptable principle. Hence, among all stakeholders, students are to be considered as the primary stakeholder and their opinion plays an important role in evaluation of service quality in higher education. Consequently it becomes necessary to identify the determinants of service quality from the stand point of students being the primary customer, but in spite of this, very few studies have been done in this area particularly on exploring the dimensions to measure service quality in higher education in the perspective of students in the Indian context. Indian education sector has gained significant attention from policymakers, investors and media till now. There has been an increase of 11.5 times in Universities, 12.35 times in colleges, 60.21 times in student's enrolment, 25 times in teachers and 20 times in non-teaching staff during last 50 years (Parikh, 2003).

It was filled with enthusiasm at one level and anxieties at another level. This year will continue to be an important year with increasing demand for education and corresponding new ways of meeting those demands. Education is now going a sea change in the recent past. The focus is shifted from public sector to the private sector providers in education sector. Over the last decade, a flurry of research on customer satisfaction and service quality has been produced and continues to do so at a very fast pace. It is inevitable to measure the student's perception on the service quality of the institutes for their future enrichment.

\section{REVIEW OF LITERATURE:}

Chang and Yu (1982) attempted to develop a model to determine the demand for faculty in southern states of US. Pal al. (1988) tried to study the faculty shortage in certain areas of study in the US. JohnesS (1990) has studied the economics of higher education in which particular attention is given to the demand for and supply of higher education, the role of higher education institutions as multi- product firms, the optimal pattern of provision, and the academic labour market. Cheng (1993) has presented a selective review of the application of Operations Research (OR) in higher education administration. O'Brien and Deans (1996) have carried out a study at the University of Strathclyde and tried to examine the concept 
of adapting industry models to higher education, with specific reference to the idea of an educational supply chain, in which employers, students, university staff, schools and colleges work in collaboration to ensure that the needs of all are satisfied. Avdjieva and Wilson (2002) have used a developmental perspective to characterize quality initiatives in the higher education systems of four countries: Australia, New Zealand, the UK, and North America. Srikanthan and Dalrymple (2003) suggest that the quality in Higher Education (HE) debate is currently narrowly focused, essentially around adapting industrial quality systems and have tried to give a general perspective on quality in higher education. The Revitalizing Technical Education (2003), document released by the Ministry of Human Resource Development (MHRD) in 2003, notes that there is a shortfall of 26,000 $\mathrm{PhDs}$ and 30,000 M.Techs in the country. The seven established IITs are already short of faculty. As per the IIT Review Committee 2004, the total strength of faculty in all the IITS in 2002-03 (2,375) was 27\% less than their total sanctioned strength $(3,263)$ which is due to some of these institutes acting as a mentor institutes to the new IITs and whose students they will be servicing for a few years.Bornman (2004) has tried to give a general perspective on quality in higher education using the case of a South African University. Marshall et al. (2006) examined the alternative sources of doctoral accounting faculty by comparing accounting faculty with non-accounting doctorates and accounting faculty with accounting doctorates. Swartz et al. (2007) have examined the challenges facing business schools because of the identified shortage of doctoral level faculty. Finkle (2007) showed that there is still a strong demand for entrepreneurship faculty despite a slowdown in the market over the past few years, with demand outpacing supply. La u (2007) has attempted to apply the concepts of supply chain management to the University of Hong Kong for procurement items and also for services, both academic and nonacademic. Gulhati (2008) seven IITs are still facing a short fall of about $25 \%$, thanks to reservation of seats for students belonging to the $\mathrm{SC} / \mathrm{ST} / \mathrm{OBC}$ categories; the number of students will increase by $50 \%$. Comm and Mathaisel (2008) have tried to draw lessons from best practices followed by Wal Mart for sustaining higher education. Singh (2008) has studied the opportunities for entrepreneurship faculty members and the statistics, issues and implications for entrepreneurship education. Ruff et al. (2009) studied the attempts being made to address the potential shortage of accounting faculty in higher education in the US. Finch et al. (2010) have reported the results of a national survey to determine the amount of salary premium required to bring vacated management faculty lines back up to competitive market levels.

\section{NEED FOR THE STUDY:}

According to NASSCOM report it reveals that the universities and colleges are not able to fulfill the need for manpower. Even though company's requirement is huge but they don't hire at all the aspirants they analyze the prospective candidates on certain skills and abilities.

According to UGC report despite of growth in terms of number of colleges and enrolment the numbers are not sufficient enough to cater to the education needs of increasing young population of this country. It is also evident from the above report that there is lack of interest among 
students to opt for research projects that could be attributed to the reason such as they prefer lucrative jobs which could fetch them more money than spending years in doing research and getting very little compensation during that period. The reason could also be that there is lack of motivation to do research and the teaching community cannot shy away from the fact that they are not able to generate that motivation and interest among their students. The responsibility also lies on the bodies like UGC and AICTE and the Universities to provide adequate facilities to young researchers along with good compensation for them to proceed in that direction.

This is the time to revamp and innovate ourselves and move towards quality improvement programmes in engineering education sector. Let us adopt a professional way to inculcate the habit of quality \& to embrace it in our engineering education so as to produce global engineers tomorrow. Hence as engineering is the ever hot cake and first choice of students, let engineering colleges know what these aspiring, young would be engineers require from an engineering institute.

\section{OBJECTIVE OF THE STUDY:}

- To know the problems/weakness of Indian Engineering education.

- To suggest remedial measures for improvement in the Engineering education.

\section{SCOPE OF THE STUDY:}

This article includes the views of Engineering faculties and students who are urging the institutes to embrace quality initiatives. It includes the importance of Quality which is lacking in present engineering education system of India, what are the reasons behind this problem and what measures we can take up to improve its quality up to the internationally accepted level. The study could create awareness among the Faculties, Students\& engineering institutions as well that, if they have to stay in the international race of quality education they need to go for the implementation of highly systematized quality innovative initiatives to maintain global levels and to be competent with traditional base \& international outlook as well.

\section{RESEARCH METHODOLOGY:}

The present study is based on secondary data, which is collected from various journals, articles, research papers, Newspapers etc.

\section{HIGHER EDUCATION: WORKFORCE IN INDIA:}

With elementary education becoming universal in India, secondary education is targeted in the next phase. Higher education will take time to be transformed into a mass education initiative. At present, India has more than 15,000 colleges with about 10 million students. More than 2/3rd of these colleges are Arts, Science, Commerce\& Management $(18 \%) \&$ oriental learning colleges. The recent growth is much greater in professional colleges especially Engineering, Management \& Medicine as well as private vocational courses, catering especially to the IT sector. There are over 1,250 medical colleges.

The National Mission on Education through Information and Communication technology (NMEICT) has been envisaged to leverage the potential of ICT to provide high-quality interactive education modules over the internet / intranet in anytime \& anywhere mode for every student of higher education institutions in the 
country. However, even well-framed policies and sophisticated technologies would fail if there is lack of adequate capacity building- be it training of teachers in using technology or content development. Although India has been witnessing tremendous growth in the IT sector, there still remain large chunks of population who are untouched by technology advancements.

ISSUES OF CONCERN IN HIGHER EDUCATION (ENGINEERING) (An exhaustive list of weakness \& suggestions to improve quality of higher education in India based on various SERVQUAL dimensions developed by Parashuraman \& Zeithmal is listed below)

\section{Tangibility Dimension}

1. All institutions should have required advanced infrastructure.

2. Institute laboratories should be equipped with advanced machinery.

3. Library must be well furnished, spacious and equipped with all journals.

4. The quality of food provided in canteen should be good at reasonable price.

5. Class rooms should be well furnished, spacious and ventilated.

6. Class rooms should be equipped with LCD projector, podium and mike.

7. Transport facility must be available cheaply in \& outside of the institute.

8. Digital library \& video conferencing rooms should be available in institutes.

9. IT Lab should be there throughout the course

10. Institute must have Newsletters Quarterly/Half yearly/Yearly
11. Faculties must use PPTs/OHP/Mike to deliver lectures.

12. aculties should not teach from their personal notes rather than prescribed text books.

13. Institutes must have Entrepreneurship Development Cell (EDC).

14. Institutes should have medical facility, well equipped ambulance in campus.

15. Institutes should have suggestion and complaint boxes.

16. Institutes must have hygienic Restrooms/Toilets.

17. Institutes should have gym facility and regular health checkups in campus.

18. Institutes must have a big play ground.

19. Institutes must have a big auditorium.

20. Institutes should have yoga sessions, Judo \&karate sessions, \& meditation rooms.

21. Institute should have ATM facility.

22. Institute must have mineral water plant in campus.

\section{Reliability Dimension}

23. Faculty members must be well experienced.

24. Placements must be given top priority in institutes.

25. Faculties teaching methods should be appropriate.

26. The system of evaluation and examination system should improve.

27. Institutes must interacts and collaborates with industry regularly.

28. Institutes must conduct guest lecturers monthly. 
29. Inspection committee must interacts with Faculties separately

30. Management must sponsor various competitions.

31. Faculties should deliver lectures in English.

32. Institute should award best students from each course every year.

33. Senior faculties should be more in number than freshers.

34. Your HOD/Principal interact with you when there is a need.

35. There should not be problems in getting scholarship from Government.

\section{Assurance Dimension}

36. In a year minimum two academic events must be organized by students.

37. News paper subscription must be provided to students throughout their course.

38. Any Journals / Association membership must be provided to all faculties.

39. University inspections must be conducted regularly in institutes.

40. Institutes must have more doctorates for all streams.

41. Faculties and students should be a member of club/forum.

42. Placement information must be available for all.

\section{Empathy dimension}

43. Students should not prefer to go for dummy projects for live projects.

44. Students should be rewarded \& recognized for their excellent performances in various activities.

45. Institutes must encourage sports hour.
46. Students' innovative ideas should be welcomed by faculties.

47. Faculties must understand students' problems at institutes \& try to solve them.

48. Education fee should be reasonable.

49. Institute should conduct remedial classes for average students regularly.

50. Students' talents must be recognized and rewarded in various streams every year.

51. Faculties should stress on Telugu/other medium students.

52. Institute should appoint mentors and counsellors for students.

53. Poor Parents should encourage students to go for higher education.

54. Reservation should not a problem to talented students.

55. Faculties should conduct special programs like Mock interviews etc.,

\section{Responsiveness Dimension}

56. Internship program for students should start in institutes.

57. Institute must have a short term curricular/extracurricular classes.

58. Faculties should conduct classes regularly and interestingly.

59. Problems should be resolved by heads immediately with positive attitude.

60. Faculties should not be biased towards average students.

61. Faculty should encourage students for various competitions.

62. Passed out employed students information must be provided.

63. Best faculty award should be nominated 
by students based on their feedback on various parameters.

64. Principal must interacts with students at least monthly.

65. Faculties should conduct Role play, Jam sessions, Quiz, Group discussions, presentations regularly.

66. Faculties must encourage students to conduct seminars, conferences, workshops etc.,

67. Feedback must be taken from students on a monthly basis.

\section{LIMITATION OF THE STUDY:}

- The present article is confined to mostly secondary data although some points are written after discussion with the students of Engineering from reputed colleges, but presence of biasness cannot be ruled out.

- $\quad$ This study is limited only to Engineering sector of Indian higher education.

- No statistical analysis has been done because of time limitation.

- The points discussed under the heading "Issues of concern in higher education (engineering)" will not apply to all Engineering institutes/Colleges.

\section{SCOPE FOR FURTHER RESEARCH:}

There is no end to learning and research. Whatever weaknesses and suggestions are identified is just a drop of water in the ocean of education. As the present research is done on engineering branch, future research can be done in other branches like Management, Pharmacy etc. Approved \& appropriate statistical tools can be used to give more reliable results for reference in future. Further this research is based basically on secondary data, but in future primary data with a structured Questionnaire can be used for authenticity.

\section{CONCLUSION:}

Where there is a will, there is a way. This proverb may be old but it is showing the future which depends upon our today's' willingness. Education is the key to the resurgence of India. Our technical education system has world's second largest population in engineering education. The need is to awake and realize the real business needs \& to prepare students accordingly. Change is needed both in the mindset of faculty and student as well as curriculum. To communicate the change, mechanisms beyond existing processes will need to be developed.

\section{REFERENCES:}

- $\quad$ Simon Marginson, 2006, Ranking Ripe for Misleading", The Australian, Dec. 6

- Richard Holmes, 2007, "The THES UNIVESITY Ranking: Are they Really World Classfl Asian Journal of University Education, MARA University of Technology, Malaysia, 1/1, 1-14.

Outlook India, June 28, 2010, pp. 33-42.

Cheng T C E (1993), "Operations Research and Higher Education Administration", Journal of Education Administration, Vol. 31, No.1, pp. 77-90.

- Finch J Howard, Allen Richard S and Weeks H Shelton (2010), "The Salary Premium Required for Replacing Management Faculty: Evidence From a National Survey", Journal of Education for Business, Vol. 85, No. 5, pp. 264-267.

Johnes Geraint (1990), "The Economics of Higher Education “, International Journal of Education Management, Vol. 4, No. 2. 
- Pal Surendra, Waldauer Charles and Bovbjerg Randall R (1988), "Imbalanced Faculty: A Persistent problem in Higher Education", Journal of Policy Analysis \& Management, Vol. 7, No.4, pp. 718-721.

- Revitalising Technical Education (2003), Ministry of Human Resources Development, Govt. of India.

- $\quad$ Srikanthan G and Dalrymple John (2003), "Developing Alternative Perspectives For Quality in Higher Business Faculty", Journal of Education for Business, Vol. 82, No.6, pp. 337-342.

- Swartz James E, Swartz Teresa A and Liang Priscilla (2007), "Market Meltdown: Recruiting Qualified Business Faculty", Journal of Education for Business, Vol.82, No.6, pp. 337-342.

- Aldridge S and Rowely J, (1998), Measuring customer satisfaction in higher education, Quality Assurance in Education, Vol. 6 (4), pp. 197-204.

- Bharathy A (2000), "Management Education: Is It ReadyFor a Millennium Change in Curriculum", University News, Vol. 38 No. 3, pp-8-10.

- Campbell T.A and Campbell D.E (1997), "Faculty / student mentor program: on performance and retention", Research in Higher Education, Vol 38 (6), pp. 727742.

- DeShields Jr. W. Kara A and KaynaE (2005), "Determinants of Business Student Satisfaction and retention In Higher Education: Applying Herzberg's Two Factor Theory", International Journal of Educational Management, Vol. 19(2), pp. 28-139.

- $\quad$ Druzdzel, M. J. and Glymour, C. (1995), "Application of the TETRAD II program to the study of student retention in US colleges", retrieved on October 2009.
Kang Lakhinder S and Sharma S (2010), The IUP Journal of Management Research, Vol. IX, No. 2, pp-38-50.

Mayo D. T , Helms M.M . andCodjoe H. M. (2004), Reasons to remain in college: a comparison of high school and college students, The International Journal of Educational ManagementVol. 18(6), pp. 360-367.

Navarro M.M. Iglesias P.M and Torres R.P (2005) , A New Management Element for Universities: Satisfaction with the offered courses, International Journal Educational Management 19(6), pp. 505-526.

Ganesh S.R. (1980) "Performance of Management Education Institutions: An Indian Sampler", Higher Education, Vol. 9, No. 3, pp. 239-253.

Khanzode V. V. (2006), "Recent Trends in Commerce and Management Education", Sterling Publishers Provate Ltd., New Delhi.

Management Education in India: Trends, Issues and Implications by Sanjeev Kumar and M.K. Dash Research Journal of International Studies - Issues 18 (January, 2011).

"Management Education in India", available at http:// ww . Sooperaarticles.com/ educationarticles/ international studies - articles/ management - education- India30505.html.

Patel I. (1996) "India", International Review of Education, Vol. 42, No. 1/3 (1996), pp. 75-96.

Sahu K.C. (1991), "Reorienting Management Education", Economic and Political Weekly, Vol. 26, No. 48, pp. M133-M136. 
- Sharma, Yogendra, Fundamental Aspects of Educational Technology, Kanishka Publications, New Delhi, 2008.

- $\quad$ Sharma B. and Roy J. A. (1996),"Aspects of the Internationalization of management education", Journal of Management Development, Vol. 15, No. 1, pp. 5-13.

- $\quad$ Sheth, N.R. (1991), "What Is Wrong with Management Education", Economic and Political Weekly, Vol. 26, No.48, pp. M123-M128.

- Ravichandran N. (2009),"A perspective on management education in India", available at http:// www. Financial express.com/printer/ news/527793.

- Various issues of University News - A Weekly journal of higher education, Association of Indian Universities, New Delhi.

- Avdjieva Maria and Wilson Marie (2002), "Exploring the Development of Quality in Higher Education", Managing Service Quality, Vol. 12, No. 6, pp. 372-383.

- Bornman Gertruida M (2004), "Program Review Guidelines For Quality Assurance in Higher Education: A South African Perspective, International Journal of Sustainability in Higher Education, Vol.5, No. 4, pp.372-383.

- Cheng T C E (1993), “Operations Research and Higher Education Administration", Journal of Education Administration, Vol. 131, No. 1, pp. 77-90.

- Chang Hui S and Yu Hsing (1982), “A Note on the Demand for Faculty in Public Higher Education", Industrial Relations, Vol. 21, No. 2, pp. 256-259.

- Comm Clare L, Mathaisel S and Dennis F X (2008), "Sustaining Higher Education Using Wal-Mart's Supply Chain Management Practices", International
Journal of sustatainability in Higher Education, Vol. 9, no. 2, pp. 183-189.

Education, Country Profile India (2008), Education Intelligence Unit (www.eiu.com). Accessed on March 23, 2009.

Faculty Shortage at IIT (2007), www.siliconindianetworking.com, April 20, 2007. Accessed on July 11, 2011.

Finch J Howard, Allen Richard S and Weeks H Shelton (2010), "The Salary Premium Required for Replacing Management Faculty: Evidence From a National Survey", Journal of Education for Business, Vol. 85, No. 5, pp. 264-267.

Finkle Todd A (2007), "Trends in Market for Entrepreneurship Faculty from 19892005", Journal of Entrepreneurship for Business, Vol. 10, pp. 1-24.

Gulhati Shashi K (2008), "Job Reservations at IITs", Financial Express, September 15.

- Hanushek Eric A and Kimko Dennis D (2000), "Schooling, Labor Force Quality and the Growth of Nations", The American Economic Review, Vol. 90, No. 5, pp. 1185-1208.

Jalote Pankaj (2008), "Where is the Faculty for New IITsff', Economic Times, July 23.

Johnes Gesraint (1990), "The Economics of Higher Education", International Journal of Educational Management, Vol. 4, No. 2.

- Lau Antonio K W (2007), "Educational Supply Chain Management: A Case Study", On the Horizon, The Strategic Planning Resource for Education Professionals, Vol. 15, No. 1, pp. 15-27.

Agarwal, Pawan. (2006). Higher Education in India. The Need for Change. 
New Delhi, India: Indian Council for Research on International Economic Relations.

- Annual Financial Statistics of Education Sector 2003-4, MHRD, Government of India, New Delhi, 2005.

- Annual Report Ministry of Human Resource Development, Government of India 2006-2007.

- Bennell, P. y T. Pearce, 1998, "The internationalisation of higher education: exporting education to developing and transitional economies", IDS Working Paper 75, Institute of Development Studies, University of Sussex, Brighton.
Central Advisory Board of Education (CABE) Committee Report on Financing of Higher and Technical Education, June 2005.

Collis, B. and M.C. van der Wende (eds.) (2002). Models of Technology and Change in Higher Education: An international comparative survey on the current and future use of ICT in Higher Education. Enschede: University of Twente.

Draft Report of Working Group on Higher Education for the XI Plan, Planning Commission, Government of India (2007)

http:// www.aicte -

India.org/misappgrowth.html. 